\title{
Implementasi Akad Murabahah dalam Penentuan Harga dan Margin Pembiayaan pada BMT di Tulungagung
}

\author{
Muhammad Ali Tamrin'; Dedi Suselo² \\ STIS Faqih Asy'ari ${ }^{1}$; IAIN Tulungagung ${ }^{2}$ \\ Sumbersari, Kencong, Kepung, Kediri ${ }^{1} ;$ Jl. Mayor Sujadi Timur No 46 Tulungagung $^{2}$ \\ E-mail : ali.tamrin88@gmail.com ${ }^{1}$; dedi_suselo@iain-tulungagun.ac.id ${ }^{2}$
}

Diterima: 15 Mei 2018; Direvisi: 26 Juni 2018; Diterbitkan: 28 Juni 2018

\begin{abstract}
Abstrak,
Semakin berkembangnya BMT di wilayah Tulungagung terjadi banyak praktik BMT masih menggunakan rujukan suku bunga konvensional. Fenomena ini didasarkan pada kenyataan bahwa proses penentuan harga jual murabahah adalah tetap menggunakan metode pembebanan bunga flat rate dan prinsip cost of fund yang merupakan pikiran utama dalam lembaga konvensional. Kajian ini berfokus pada pendeskripsian aplikasi pembiayaan murabahah pada BMT di Tulungagung. Mendeskripsikan penetapan harga dan margin pada pembiayaan murabahah BMT di Tulungagung. Penelitian ini menggunakan pendekatan penelitian kualitatif dengan pengumpulan data menggunakan teknik observasi, wawancara. Hasil menunjukkan bahwa 1) Aplikasi pengajuan pembiayaan murabahah pada BMT Tulungagung memiliki kebijakan tersendiri terhadap persyaratan administrasi dalam kelengkapan pengajuan pembiayaan murabahah. Selain itu, didalam proses pembelian BMT tidak melakukan pengadaan barang secara langsung atau memesankan untuk nasabah melainkan mewakilkan langsung kepada nasabah dan nasbah sendiri membelanjakan uang tersebut atas barang yang diinginkannya. 2). Mekanisme penentukan harga dan margin pembiayaan murabahah BMT di Tulungagung tetap menggunakan metode flat rate. Selain itu juga ada yang menggunakan sistem annuitas yang merupakan metode pembayaran mendahulukan angsuran margin setelah itu membayar angsuran pokok pada waktu jatuh tempo yang dikehendaki.
\end{abstract}

Kata Kunci: Harga, Margin Pembiayaan, Murabahah, Baitul Maal wat Tamwil

\begin{abstract}
,
The growing BMT in Tulungagung area there are many practices BMT still use conventional reference rate. This phenomenon is based on the fact that the process of determining the selling price of murabahah is still using the method of flat rate interest rate and cost of fund principle which is the main thought in conventional institution. This study focuses on the description of murabahah financing applications in BMT in Tulungagung. Describe the pricing and margin on murabahah financing of BMT in Tulungagung. This research uses qualitative research approach with data collection using observation technique, interview. The result shows that 1) Murabaha murabahah filing application on BMT Tulungagung has its own policy on administrative requirements in the completeness of murabahah financing application. In addition, in the process of purchasing BMT does not directly procure goods or order for the customer but instead directly represent the customer and his own expenditure spend the money on the goods he wants. 2). The mechanism of price determination and margin of
\end{abstract}


murabahah murabahah in Tulungagung still use the flat rate method. In addition there is also using annuity system which is the method of payment put the margin installment after that pay the principal installment at the desired maturity date.

Keywords: Price, Financial Margin, Murabahah, Baitul Maal wat Tamwil

\section{PENDAHULUAN}

Lembaga Keuangan Syariah yang merupakan lembaga sosial ekonomi, mempunyai ruang lingkup mikro yaitu Baitul Maal wa Tamwil (BMT) yang semakin menunjukkan eksistensinya. Di Wilayah Provinsi Jawa timur perkembangan BMT atau lembaga keuangan mikro syariah juga mengalami perkembangan sangan pesat, salah satunya yaitu di Kabupaten Tulungagung. Tulungagung merupakan salah satu Kabupaten yang banyak berdiri BMT terbesar diwilayah Jawa Timur, memang kalau dilihat dari segi aset Tulungagung kalah besar dibanding dengan BMT Sidogiri Pasuruan, akan tetapi kebesaran asset tersebut hanya di dominasi oleh satu atau dua BMT besar saja yakni BMT Sido giri. Wilayah Tulungagung sendiri banyak berdiri BMT-BMT dengan jumlah aset yang kompetitif dan itu tidak hanya di dominasi oleh segelintir BMT saja tetapi jumlahnya mencapai puluhan. Sebagai contoh BMT yang ada di daerah Tulungagung, BMT Pahlawan dengan 5 kantor cabangnya, BMT Arrahman dengan 6 kantor cabang, BMT ISTIQOMAH dan BMT SAHARA masing dua cabang, BMT Sinar Mas, BMT Al Islam, BMT Insan Cinta, BMT al Ikhlas, Puskopsyah BMT, Kopsyah BMT Muamalah, Harun, Dinar Amanah, Sinar Amanah, Nur Hidayah, Nasroh, Istiqlal, Ummatan Wassathon dan masih banyak BMT lainya. ${ }^{1}$ Sedangkan menurut data Dewan Koperasi Induk Daerah (Dekopinda) per Desember 2012 ada 58 BMT yang tersebar di sembilan belas kecamatan di Tulungagung. ${ }^{2}$

Tonggak penting lain yang memperkuat gerakan BMT adalah didirikannya Pusat Inkubasi Bisnis Usaha Kecil (PINBUK) pada tahun 1995 oleh Ketua Umum MUI, Ketua Umum ICMI dan direktur utama Bank Muamalat Indonesia. ${ }^{3}$ BMT dalam menjalankan usahanya tidak dapat dipisahkan dari prinsip-prinsip syariah yang mengatur seluruh operasionalnya. Prinsip dasar inilah yang akan dijadikan sebagi pijakan atau landasan untuk mengembangkan produk-produk BMT yaitu:4 Antara lain dalam bentuk jual beli (murabahah), sewa-menyewa (ijarah), sewa beli (ijarah muntahia bit tamlik), bagi hasil mudharabah atau musyarakah),

\footnotetext{
1 Dokumentasi PINBUK Tulungagung.

2 Dokumentasi DEKOPINDA Tulungagung

3 Perhimpunan BMT Indonesia, Haluan BMT 2020, h.10

4 http://www.microficenter.com, produk-ekonomi-islam artikel-ekonomi-syariah, diakses tanggal 27 April 2013
} 
penitipan (wadiah), mewakilkan (wakalah), penjaminan (kafalah), anjak piutang (hiwalah), pegadaian (rahn), pinjam-meminjam (qardh).5 Tugas pokok lembaga pembiayaan adalah menghimpun dana dari masyarakat dan menyalurkannya kepada masyarakat yang memerlukannya sehingga peranan pembiayaan menjadi sangat penting. ${ }^{6}$

Seperti halnya bank syariah, kegiatan Baitul Maal wa Tamwil (BMT) adalah melakukan penghimpunan (prinsip wadiah dan mudharabah) dan dana (prinsip bagi hasil, jual beli dan ijarah) kepada masyarakat. Kebanyakan penyaluran dana dengan prinsip jual beli dilakukan dengan akad murabahah, salam, ataupun istishna. Penyaluran dana dengan prinsip jual beli yang paling dominan adalah murabahah, walaupun tidak menuntut kemungkinan ada banyak produk-produk lembaga keuangan syariah yang menggunakan produk lain.

Bagi perbankan terutama bank yang berdasarkan prinsip konvensional, harga adalah bunga, biaya administrasi, biaya komisi, biaya kirim, biaya tagih, biaya sewa, biaya iuran, dan biaya-biaya lainya. Sedangkan harga bagi bank yang berdasarkan prinsip syariah adalah bagi hasil. Bagi bank yang berprinsip konvensional pengertian harga berdasarkan bunga terdapat tiga macam yaitu harga beli, harga jual dan biaya yang dibebabkan kepada nasabahnya. Harga beli adalah bunga yang diberikan kepada para nasabah yang memiliki simpanan seperti jasa giro, bunga tabungan dan bunga deposito, sedangkan harga jual merupakan bunga yang dibebankan kepada penerima kridit. Kemudian biaya ditentukan kepada berbagai jenis jasa yang ditawarkan.7

Sepertihalnya penetapan harga di BMT Sahara dan Kopsyah BMT Muamalah, kedua lembaga keuangan tersebut didalam menentukan harga khususnya dalam pembiayaan murabahah menggunakan standarisasi yang merujuk pada penetapan harga pasar setempat. Akan tetapi didalam penetapan margin atau keuntungan, di BMT Sahara cenderung memberikan ruang gerak didalam tawar menawar antara Pegawai BMT terhadap calon pembeli (Nasabah), rata-rata didalam persentase pengambilan keuntungan berkisar $1 \%$ sampai dengan 2,5 \% tergantung negosiasi dan kesepakatan kedua belah pihak. ${ }^{8}$ Sementara di Kopsyah BMT Muamalah cenderung memberikan margin rendah yakni kisaran antara 0.5\% sampai $3 \%$, akan tetapi didalam proses penetapan margin pihak BMT Muamalah melihat sistem angsuran nasabah tersebut, jika didalam angsuranya menggunakan sistem flat (pokok plus margin) maka cenderung murah, namun jika menggunakan sistem pembayaran anuitas

5 Agustianto, BMT Sebagai Lembaga Ekonomi Rakyat,www.agustianto.com, diakses tanggal 27 April 2013 Pers), h. 36

6 Veitzal Rivai,dan Andria Permata Veitzal, Islamic Financial Managemen, (Jakarta :Rajawali

7 Kasmir, Pemasaran Bank, (Jakarta: PT Raja Grafindo Persada, 2003), h. 151

8 Hasil wawancara dengan Rifa' Kusworo (Kabag Pembiayaan BMT Sahara), o2 April 2013. 
(pembayaran yang didahulukan marginnya saja dan sesuai kesepakatan sedangkan pokoknya dibayar diakhir atau keika jatuh tempo) maka cenderung lebih mahal dari pada sistem flat. 9

Tulungagung dipilih sebagai lokasi penelitian membuka peluang besar dalam orisinalitas penelitian ini. Sebab sejauh pengamatan peneliti, wilayah ini belum pernah dikaji dari sisi prosedur pembiayaan dari awal hingga mekanisme penetapan harga dan margin. apalagi penelitian ini bersifat multi kasus sekaligus multi situs biar menghasilkan penelitian yang bersifat komperehensif dengan mengambil 5 (lima) BMT sebagai sample penelitian dari total 58 BMT yang ada di Tulungagung.

\section{TINJAUAN TEORITIK}

\section{Murabahah}

Sistem jual beli sendiri terdiri dari tiga bentuk yaitu murabahah, tauliyah, dan wadhi'ah. Murabahah adalah jual beli dengan harga pertama disertai tambahan keuntungan. Tauliyah adalah jual beli dengan harga pertama tanpa ada penambahan atau pengurangan. Sedangkan wadhi'ah adalah jual beli dengan harga jual beli rendah dari harga pertama. Murabahah secara bahasa adalah bentuk mutual (bermakna: saling) dari kata ribh yang artinya keuntungan, yakni pertambahan nilai modal (jadi artinya saling mendapatkan keuntungan). Menurut terminologi ilmu fiqih artinya murabahah adalah menjual dengan modal asli bersama tambahan keuntungan yang jelas. ${ }^{10}$

\section{Skema Murabahah}

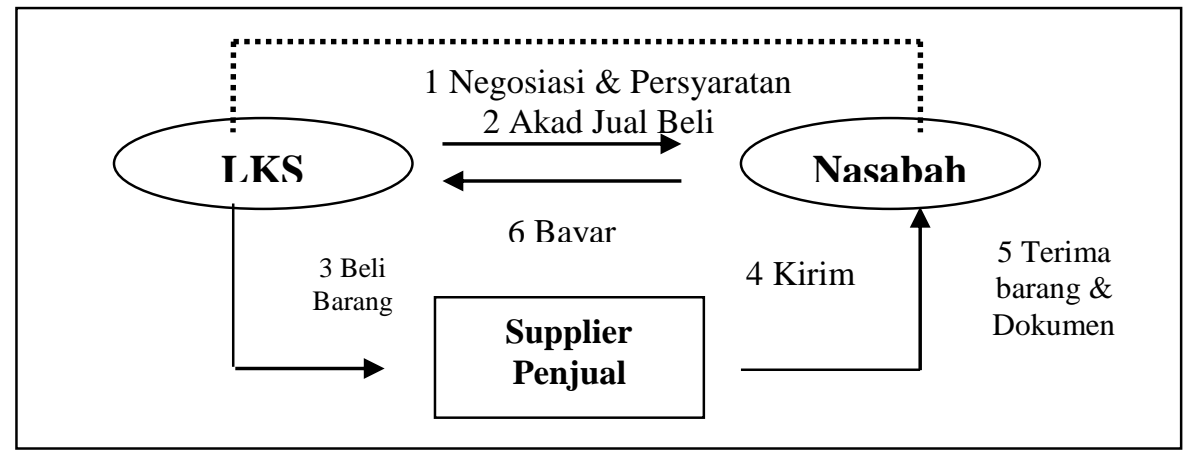

Gambar 1. Skema Gambar Asli Murabahah ${ }^{11}$

Sumber : Syafï Antonio, Lembaga Keuangan Syariah dan Praktek Keuangan 2013

9 Hasil wawancara dengan Weny Wahyuningtas (Karyawan Kopsyah BMT Muamalah), o5 April

10 Abdullah Al-Muslih dan Shah Ash-Shawi, "Fikih Ekonomi Keuangan Islam", (Cetakan Pertama, Jakarta, 2004), hlm. 198.

${ }_{11}$ Muhammad Syafi'i Antonio, "Bank Syariah Bagi Bankir \& Praktek Keuangan, (Jakarta: Tazkiya, 1999) h. 166 


\section{Implementasi Akad Murabahah dalam Penentuan Harga dan Margin Pembiayaan Pada BMT di Tulungagung \\ Muhammad Ali Tamrin dan Dedi Suselo \\ DOI : $\mathrm{xxxxxxx}$}

Lembaga Keuangan Syariah sebagai penjual dan nasabah sebagai pembeli, barang diserahkan segera dan pembayaran dilakukan secara tangguh. ${ }^{12}$

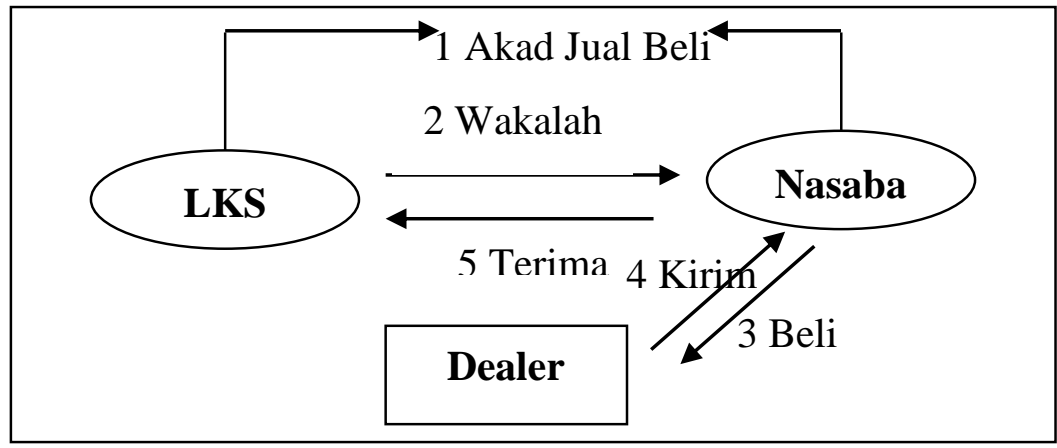

Gambar 2. Skema Pengembangan Murabahah Sumber: Penjelasan Fatwa No. o4/DSN-MUI/IV/20oo

Jika pihak bank ingin mewakilkan kepada nasabah untuk membeli barang pihak ketiga (supplier), maka kedua pihak harus menandatangani kesepakatan agensi (agency contract), dimana pihak bank memberikan otoritas kepada nasabah untuk menjadi agennya guna membeli komoditas dari pihak ketiga atas nama bank, dengan kata lain, nasabah menjadi wakil bank untuk membelikan komoditas. Kemudian, nasabah membeli komoditas atas nama bank, dan kepemilikannya hanya sebatas sebagai agen dari pihak bank. Selanjutnya, nasabah memberikan informasi kepada pihak bank bahwa ia telah membeli komoditas, kemudian pihak bank menawarkan komoditas tersbeut kepada nasabah, dan terbentuklah kontrak jual beli dan komoditas kemudian pindah menjadi milik nasabah dengan segala risikonya. Menurut Ahmad Muhyiddin Ahamad dari Kuwait Islamic Bank, transaksi ini diperbolehkan dan lazim disebut dengan al murabahah lil amir bissyira' bil wakalah. ${ }^{13}$

\section{Dasar Hukum Jual Beli Murabahah}

Beberapa dalil dalam al-Quran dan al-Hadits yang menjelaskan tentang transaksi jual-beli murabahah :

1. QS. Al Baqarah ayat 275:

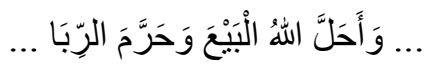

Terjemahnya :

"Dan Alloh telah menghalalkan jual beli dan mengharamkan riba. "

12 Muhammad, “Manajemen Bank Syariah",(Jakarta: UPP AMP YKPN, 2005), h. 91

${ }^{13}$ Penjelasan fatwa. Op.Cit., No. 04/DSN-MUI/IV/2000 
2. HR. Bukhari, Kitab Al Buyu':14

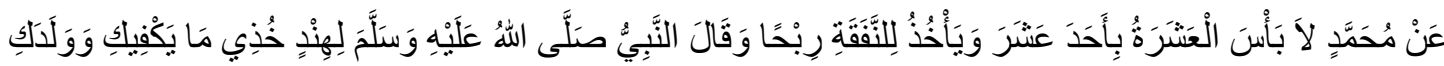

$$
\begin{aligned}
& \text { بِالْمَعْرُوفِ (صحيح البخاري) }
\end{aligned}
$$

Artinya:

"Dari Muhammad, tidak bahaya (menjual harga) sepuluh dengan sebelas, dan dia mengambil untung sebagai nafkah. Dan bersabda Nabi saw kepada Hindun:" Mengambillah engkau pada apa-apa yang mencukupi bagimu dan anak mu dengan sesuatu yang baik.”

3. HR. Bukhari, Kitab Al Buyu':

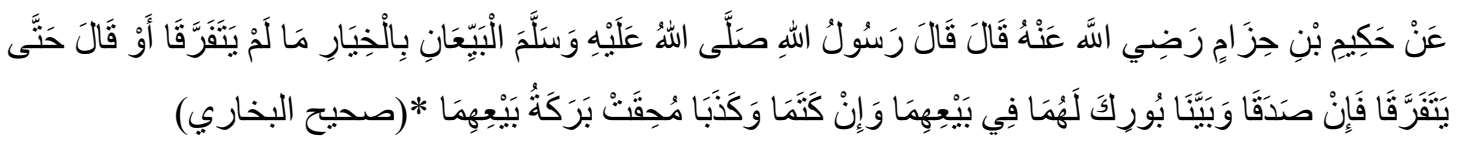
Artinya :

"Dari Hakim bin Hizam berkata ia, bersabda Rasululah saw:" Dua orang yang berjual beli itu berhak memilih selama keduanya belum berpisah", atau beliau bersabda:" Sehingga keduanya berpisah." Jika keduanya jujur dan terus-terang, maka keduanya mendapat berkah dalam jual-belinya. Jika keduanya menyembunyikan dan berdusta maka dihapuslah berkah jual-belinya itu.”

Kaidah Ushulul Fiqh :

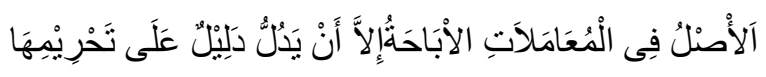

Artinya :

"Pada dasarnya semua bentuk muamalah boleh kecuali ada dalil yang mengharamkan."

\section{Harga dan Margin}

1. Pengertian Harga

Harga adalah sesuatu yang bernilai yang harus direlakan oleh pembeli untuk memperoleh barang atau jasa. Di dunia lembaga keuangan, ini mencakup biaya-biaya transaksi, suku bunga, dan saldo minimum atau kompensasi. ${ }^{15}$ Harga jual produk mempunyai fungsi ganda. Fungsi pertama harga, adalah sarana untuk memenangkan persaingan dipasar. Fungsi kedua, harga adalah sumber keuntungan perusahaan. ${ }^{16}$

${ }_{14}$ Mahrus ali, Terjemah Bulughul Maram..., h. 348

${ }^{15}$ Setyo Soedrajata, "Manajemen Pemasaran Jasa Bank", (Jakarta : PT Ikral Mandiri Abadi, 2004), h 57.

${ }^{16}$ Siswanto Sutojo, “Manajemen Terapan Bank”, ( Bandung,Pustaka Binaan Pressindo, 1997),

h. 132 
Harga adalah bunga, biaya administrasi, biaya provisi dan komisi, biaya kirim, biaya tagih, biaya sewa, biaya iuran, dan biaya-biaya lainnya. Sedangkan harga bagi bank berdasarkan prinsip syariah adalah bagi hasil. ${ }^{17}$

2. Tinjauan Penentuan Harga Menurut Syariah

Margin biasa disebut dengan keuntungan, bahkan ada yang mengatakan margin itu sebagai harga jual, menurut Bank Indonesia pada suatu transaksi jual beli yang ideal, bank syariah harus dapat menghitung dan memisahkan 'real costs' dan tingkat keuntungan yang diinginkan oleh bank sebagai dasar penetapan marjin. Demikian pula pada transaksi investasi, suatu bank syariah harus dapat menentukan tingkat keuntungan berdasarkan kinerja keuangan yang nyata dari suatu perusahaan. Namun demikian, pada kenyataannya marjin keuntungan pada transaksi jual beli masih di benchmark biaya perolehan dan handling kelompok-kelompok komoditas yang akurat sebagai indikator penetapan marjin. Demikian pula pada transaksi investasi, belum tersedianya benchmark yang dapat menggambarkan proyeksi profitabilitas bidang usaha serta belum tersedianya metode perhitungan standar atas biaya-biaya yang dapat diperhitungkan dalam penentuan bagi hasil, mengakibatkan bank mengambil benchmark yang sarana prinsip tidak mengindikasikan tingkat produktivitas nyata jenis usaha. ${ }^{18}$

\section{METODE PENELITIAN}

\section{Pendekatan dan Rancangan Penelitian}

Penelitian ini merupakan penelitian lapangan (field research) dan jenis penenlitian yang digunakan adalah kualitatif. Penelitian kualitatif mempunyai cirri-ciri, yaitu ; (1) dilakukan pada latar alamiah (natural setting) sebagai sumber data langsung dan peneliti sebagai instrument kunci, (2) bersifat deskriptif, yaitu menggambarkan situasi tertentu, (3) lebih memperhatikan proses dari pada hasil atau produk, (4) analisis datanya cenderung induktif dan (5) desain bersifat sementara. ${ }^{19}$ Penelitian ini bertujuan untuk deskriptif, dimana penelitian yang dilakukan bersifat mandiri yang bertujuan untuk menganalisis tentang aplikasi pembiayaan dan penerapan metode penentuan harga serta margin pada pembiayaan murabahah.

${ }_{17}$ Kasmir, “Manajemen Perbankan”, (Jakarta: PT Raja Grafindo Persada, 2003), h. 196

${ }^{18}$ Ahmad Buchori, dkk "Standarisasi Akad perbankan Syariah",... 51

${ }^{19}$ Lexy J. Moleong, Metodologi Penelitian Kualitatif, (bandung;Remaja Rosda karya, 2000), h. 


\section{Sumber Data}

Data yang digunakan dalam penelitian ini adalah berupa data kualitatif yang bersifat induktif dalam arti cara menerangkanya dari data kearah teori. ${ }^{20}$ Yang bersumber dari data primer dan sekunder, data primer berupa sumber data yang langsung memberikan data kepada pengumpul data (peneliti), sedangkan data sekunder adalah sumber data yang tidak langsung memberikan data kepada pengumpul data (peneliti) atau data yang diambil peneliti sebagai pendukung atas penelitian dari sumber-sumber yang dapat dipercaya dan dipertanggung jawabkan secara ilmiah. Yaitu dengan melakukan studi pustaka melalui buku, artikel, internet, jurnal. Sedangkan data-data yang digunakan diantaranya adalah;

1. Teori-teori yang penulis ambil dari berbagai literature.

2. Data-data yang diambil lembaga keuangan syariah baik bank syariah atau BMT tempat penelitian.

3. Penjelasan-penjelasan beruapa lisan yang nantinya penulis terima. ${ }^{21}$

Adapun data primer yang digunakan dalam penelitian ini adalah hasil wawancara terhadap Manajer, Pengelola atau khususnya bagian pembiayaan yang sekiranya peneliti butuhkan dan memberikan sumber-sumber mengenai tema penelitian, sedangkan data sekunder yang digunakan peneliti adalah berupa dokumentasi baik berupa foto-foto transaksi, brosur, dokumentasi pengajuan pembiayaan, slip pembayaran, serta bahan-bahan yang berkaitan dengan penelitian ini.

\section{Tempat Penelitian}

Lokasi penelitian ini adalah Kabupaten Tulungagung, Subyek penelitianya adalah para manajer atau pengelola dan nasabah dari beberapa BMT yang ada di kota tersebut. BMT yang menjadi obyek penelitian adalah BMT yang dipilih secara purposive sampling agar dapat mewakili golonganya. ${ }^{22}$ BMT-BMT tersebut adalah BMT Sahara Kauman, Kopsyah BMT Muamalah Bago, Kopsyah BTM Annur Bandung, BMT Istiqomah Karangrejo, BMT Pahlawan Tulungagung. Masing-masing BMT tersebut diambil 2 responden yang terdiri dari pengelola dan nasabah yang dipilih secara acak (random sampling) sebagai sampel yang diharapkan dapat mewakili jumlah populasi yang ada.

${ }^{20}$ Sugiono, Penelitian Kualitatif,(Bandung: Alfabeta, 2005), h. 42

${ }^{21}$ Ibid..., h. 62

${ }_{22}$ Nana Sudjana, Tuntunan Penyususunan Karya Tulis Ilmiah, ( Bandung; Sinar Baru Algesindo, 2003), h 73 . 


\section{Teknik Pengumpulan data}

Teknik pengumpulan data yang diperlukan dalam penelitian ini, meliputi beberapa hal antara lain:

- Dokumentasi

Salah satu jenis kegiatan yang dilakukan penulis dalam rangka mengumpulkan bahanbahan penelitian adalah dokumentasi baik berupa foto-foto transaksi, brosur, dokumentasi pengajuan pembiayaan, slip pembayaran, hasil wawancara atau rekaman, dan juga struktur organisasi.

- Observasi atau Pengamatan Langsung

Dimana penulis melakukan pengamatan langsung kelapangan terhadap prosedur pembiayaan dan praktik kebijakan atau metode dalam penentuan harga (margin) pembiaayaan murabahah.

- Interview atau wawancara mendalam

Metode ini digunakan untuk mendapatkan informasi secara langsung tentang prosedur pengajuan pembiayaan murabahah dan juga kebijakan penentuan harga (margin) pada jual beli murabahah yang ada di BMT, dimana informasi yang diperoleh adalah dari internal lembaga yang mengetahui secara jelas bagaimana kebijakan penentuan harga jual beli murabahah itu diberikan. Adapun yang menjadi instrument pengumpulan data pada penelitian ini adalah peneliti sendiri, yakni peneliti hadir secara langsung untuk mengamati, menginterview serta mendokumenntasikan sesuatu hal yang dipandang perlu, guna mencari serta mengumpulkan bahan-bahan dalam menjawab focus masalah pada penelitian yang dikerjakan.

\section{Teknik Analisis Data}

Teknik analisis yang digunakan adalah dengan menggunakan pendekatan deskriptif kualitatif yang bersifat induktif yaitu dengan cara memaparkan informasi-informasi factual yang diperoleh dari kedua BMT yang berhubungan dengan prosedur pembiayaan dan penentuan harga jual beli murabahah. Sehingga mendapatkan keadaan dan praktik yang berlangsung dalam BMT Tersebut kemudian mengevaluasinya dengan berbagai teori yang berkaitan dengan focus penelitian ini. Penelitian kualitatif adalah prosedur penelitian yang menghasilkan data deskriptif berupa kata-kata tertulis atau lisan dari orang-orang dan keadaan yang diamati. ${ }^{23}$ Penelitian kualitatif merupakan metode penelitian yang digunakan

23 Menurut Bogdan dan Taylor, mengutip dari bukunya Lexy J. Moleong, Metode Penelitian Kualitatif, (Bandung: PT Remaja Rosda Karya, 1997), h. 4 
untuk meneliti pada kondisi objek yang alamiah, dimana peneneliti adalah sebagai instrument kunci, teknik pengumpulan data dilakukan secara trianggulasi (gabungan), analisis data bersifat induktif dan hasil penenlitian kualitatif lebih bersifat makna dari pada generalisasi. ${ }^{24}$ Selanjutnya merujuk pada pandangan Miles dan Huberman sebagaimana dikutip oleh Wahidmurni, mereka menganggap bahwa analisis kualitatif terdiri dari tiga alur kegiatan yang terjadi secara bersamaan yaitu : ${ }^{25}$ a) Reduksi data; b)Penyajian data dan c) Verivikasi atau penarikan kesimpulan.

\section{Teknik Pemeriksaan Keabsahan Data}

Ada beberapa cara meningkatkan kredibilitas data kepercayaan terhadap data hasil penelitian kualitatif antara lain perpanjangan pengamatan, trianggulasi, dan diskusi dengan teman sejawat.

\section{HASIL DAN PEMBAHASAN}

\section{Aplikasi Pembiayaan Murabahah di Tulungagung}

Setiap Lembaga keuangan pasti menghendaki proses pembiayaan yang sehat yaitu pembiayaan yang berimplikasi pada investasi yang halal, baik dan mampu menghasilkan return yang diharapkan. Pembiayaan merupakan sarana untuk memutar harta untuk kegiatan investasi agar harta tersebut tidak menganggur dan dapat menghasilkan keuntungan sehingga harta tersebut semakin bertambah dan dapat diputar lagi untuk kegiatan pembiayaan produktif yang lebih besar. ${ }^{26}$ Artinya: Sesungguhnya Allah menyuruh kamu menyampaikan amanat kepada yang berhak menerimanya, dan (menyuruh kamu) apabila menetapkan hukum di antara manusia supaya kamu menetapkan dengan adil. Sesungguhnya Allah memberi pengajaran yang sebaik-baiknya kepadamu. Sesungguhnya Allah adalah Maha Mendengar lagi Maha Melihat (Q.S. An Nisa' : 58)27

Sebagaimana pembahasan sebelumnya nilai - nilai idealitas juga muncul ketika mereka memahami bahwa lembaga keuangan syari'ah adalah lembaga yang menggunakan prinsip - prinsip syari'ah begitu juga Baitul Maal wat Tamwil yang merupakan sebuah lembaga yang didalamnya ada dua konsep yaitu sebagai lembaga profit yang menghimpun dan menyalurkan dana dari, oleh dan untuk masyarakat dan juga sebagai lembaga sosial yang menyalurkan Zakat, Infaq dan Sodaqoh. Risiko sebagai konsekuensi logis dari aktivitas bisnis

24 Sugiono, Penelitian Kualitatif,..., h 2

25 Wahidmurni, Cara Mudah Menulis Proposal dan Laporan Penelitian Lapangan, (Malanag, UM Pres, 2008), h 53

${ }^{26}$ Veitzal rivai, Islamic Financial Managemen, haman 348

27 Depag RI, Alqur'an terjemah, (Bandung : Sygma 2009) h 587 
tidak mungkin dapat dihindari. Oleh karena itu, keberadaaan risiko tersebut harus dilakukan pengelolaan yang tepat sehingga keberlangsungan aktivitas bisnis tetap terjaga.

\section{Pemasaran Pembiayaan}

Sebagaimana pembahasan sebelumnya dijelaskan bahwa proses manajemen risiko pembiayaan di kedua BMT pada dasarnya melekat pada proses dan prosedur pembiayaan. Dalam hal ini divisi pembiayaan yang sekaligus analis kredit dan manajer akan melakukan analisa pembiayaan termasuk analisa risiko dan mitigasinya. Segala proses yang berkaitan dengan pembiayaan harus dilakukan dengan prinsip kehati-hatian sebagai upaya untuk mewujudkan pembiayaan yang sehat dan berimplikasi pada return yang bagus.

Adapun proses pemberian pembiayaan di BMT, pada dasarnya mempunyai pedoman yang hampir sama, yakni ${ }^{28}$ menggunakan konsep $5 \mathrm{C}$ :

\section{Character}

Penilaian terhadap karakter atau kepribadian calon mitra, dengan tujuan untuk mempertimbangkan kemungkinan bahwa mitra pengguna dana yang mengajukan pembiayaan dapat memenuhi kewajibannya. Untuk mempertimbangkan karakter calon mitra atau mitra berdasarkan kajian pada pembiayaan bermasalah adalah :

a. Mencocokan hasil wawancara dengan data yang diperoleh

b. Gaya bicara dalam wawancara; jika orang sudah menjelek-jelekan mitra lainnya biasanya ada indikasi kurang baik

c. Memandang nilai pembiayaan; jika calon mitra memandang remeh nilai pembiayaan berarti tidak punya rencana usaha dan cenderung menyembunyikan informasi usaha yang akurat

d. Menyampaikan rencana usaha; calon mitra yang tidak punya rencana usaha yang baik ingin selalu cepat dicairkan maka KJKS/UJKS harus cepat cepat juga menolak pegajuannya

e. Pergaulan di lingkungan warga

f. Loyalitas dalam bekerjasama

g. Pelayanan terhadap petugas lapang pada saat survey; hati-hati terhadap service calon mitra yang berlebihan (petugas lapang dilarang menerima oleh-oleh hasil survey)

h. Jika nasabah lama lihat prestasi pembiayaan sebelumnya

Penilaian karakter tidak dapat dilihat dan dirasakan dalam waktu yang singkat. Pertimbangan diatas merupakan langkah-langkah umum yang terjadi dalam transaksi pembiayaan.

${ }^{28}$ Veitzal rivai, Islamic Financial Managemen, haman 348 


\section{Capacity}

Penilaian secara subyektif tentang kemampuan mitra untuk melakukan pembayaran. Kemampuan ini diukur dengan catatan prestasi mitra masa lalu yang didukung dengan pengamatan dl lapangan atas usaha mitra, cara berusaha ataupun tempat berusaha. Kemampuan mitra dapat dilihat dari analisa kelayakan usaha. Perlu dicermati dalam melihat kemampuan mitra jika terjadi titik kritis, misalnya jika mitra tersebut sakit apakah ada yang menggantikan usahanya, bila terjadi musibah dan lain sebagainya apakah ada pendapatan lain yang dapat mengkaper pembayaran.

\section{Capital}

Penilaian terhadap kemampuan modal yang dimiliki oleh calon mitra, yang diukur dengan posisi usahanya secara keseluruhan melalui rasio finansialnya dan penekanan pada komposisi modalnya.

\section{Conditions}

Bagian pembiayaan BMT harus melihat kondisi perekonomian secara umum khususnya yang terkait dengan jenis usaha calon mitra. Hal tersebut dilakukan karena keadaan eksternal usaha yang dibiayai. Kasus yang dapat kita lihat misalnya pada usaha wartel. Kondisi wartel saat ini sudah sangat jenuh karena pulsa celuler lebih murah dan penggunaanya sangat praktis sehingga kondisi seperti ini kurang baik untuk dibiayai, atau sebaliknya kebutuhan akan bahan pokok tidak pernah jenuh dan sistem yang berjalan cukup baik sehingga secara conditioning usaha ini cukup baik dibiayai.

\section{Colateral}

Colateral adalah jaminan milik calon nasabah. Penilaian jaminan untuk lebih meyakinkan jika suatu resiko kegagalan pembayaran terjadi, maka jaminan dipakai sebagai pengganti dari kewajibannya. Tetapi, colateral dalam BMT lebih ditekankan pada faktor : kepercayaan, kedekatan hubungan dengan pengusaha dan kegiatan usahanya; sudah dikenal karakternya sebagai anggota BMT, dijamin oleh seseorang. Walaupun demikian perlu adanya perangkat-perangkat dan dokumen dalam jaminan, paling tidak jika mitra akan menjual barang yang dijaminkan atau pindah tempat tinggal, dapat diketahui KJKS, sehingga dapat menyelesaikan pembiayaannya. 


\section{Mekanisme Penentuan Harga dan Margin Pembiayaan Murabahah BMT di Tulungagung}

Dalam menentukan harga jual dan profit margin, BMT tidak menentukan begitu saja, yaitu harus ada beberapa pertimbangan. Dalam metode yang diterapkan untuk menentukan kedua hal tersebut. Hal itu dilakukan karena selain mendapat keuntungan, lembaga ini juga memegang teguh prinsip ekonomi yang ada di dalam aturan syariah. Apalagi lembaga ini merupakan lembaga yang berbasis syari'ah sehingga tidak hanya keuntungan duniawi saja yang menjadi titik tekannya akan tetapi keuntungan $u k h r o w i$ juga ditegakkan.

Menurut Lembaga Keuangan Syariah teori dalam perhitungan penentuan harga jual dan profit margin terdiri dari empat metode Sliding, rata-rata, Flat dan Annuitas sebagai berikut:29

1. Metode Margin Keuntungan Menurun (Sliding)

Marjin Keuntungan Menurun adalah perhitungan marjin keuntungan yang semakin menurun sesuai dengan menurunya harga pokok sebagai akibat adanya angsuran harga pokok, jumlah angsuran (harga pokok dan margin keuntungan) yang dibayar nasabah setiap bulan semakin menurun.

2. Metode Kuntungan Rata-rata

Margin Keuntungan Rata-rata adalah margin keuntungan menurun yang perhitungannya secara tetap dan jumlah angsuran (harga pokok dan margin keuntungan) dibayar nasabah tiap bulan.

3. Metode Margin Keuntungan Flat.

Margin Keuntungan Flat adalah perhitungan margin keuntungan terhadap nilai harga pokok pembiayaan secara tetap dari satu periode ke periode lainnya, walaupun baki debetnya menurun sebagai akibat dari adanya angsuran harga pokok.

4. Metode Margin Keuntungan Annuitas

Margin Keuntungan Annuitas adalah margin keuntungan yang diperoleh dari perhitungan secara annuitas. Perhitungan annuitas adalah suatu cara pengembalian pembiayaan dengan pembayaran angsuran harga pokok dan margin keuntungan secara tetap. Perhitungan ini akan menghasilkan pola angsuran harga pokok yang semakin membesar dan margin keuntungan yang semakin menurun. Dalam menentukan metode penentuan harga jual yang dilakukan oleh BMT dengan menggunakan secara kondisional

29 Muhamad, Manajemen Perbankan Syariah,... h.102 
hal ini terkait dengan tiga hal yaitu janggka waktu, penggunaan dana dan kondisi nasabah yang mempengaruhi penentuan harga jual dan profit margin di dalam BMT Tulungagung adalah kemampuan nasabah untuk melakukan angsuran dalam pembiayaan murabahah.

Dengan demikian, pada dasarnya dalam menentukan harga jual dan profit margin yang dilakukan oleh BMT yang ditelitii dan yang berada di wilyah Tulungagung menurut analisa penulis sudah baik dan mengacu pada tuntunan syariah, walaupun belum sepenuhnya, serta menerapkan sistem jual beli yaitu menggunakan negoisasi. Sudah baik disini maksudnya didalam proses penetapan harga dan margin tetap bersandarkan pada nilai-nilai syariat Islam, memang benar didalam prinsip jual beli keuntungan adalah hal mutlak yang harus didapat oleh penjual namun walaupun BMT sudah mempunyai standarisasi nilai margin lantas tidak serta merta satu pihak harus mengklaim dan mengikuti margin tersebut, sedangkan hal yang perlu dikaji ulang yakni penetapan margin keuntungan yang masih menyandarkan pada suku bunga lembga keuangan lain terutama bank konvensional, hal ini disayangakan dan harus ada alternativ pilahan atau kebijakan meengingat jikal tetap sepertini ini maka masyarakat lebih memandang lembaga keuangan syariah sebelah mata yakni mempunyaii persepsi tak ubahnya seperti lembaga keuangan konvensional, seperti yang dijelaskan dalam Al-Qur'an Suran An nisa ayat 29 sebagai berikut: Artinya "Hai orang-orang yang beriman, janganlah kamu saling memakan harta sesamamu dengan jalan yang batil, kecuali dengan jalan perniagaan yang Berlaku dengan suka sama-suka di antara kamu. dan janganlah kamu membunuh dirimu. Sesungguhnya Allah adalah Maha Penyayang kepadamu".

Dari penjelasan diatas bahwasanya sebelum terjadinya kesepakatan antara calon nasabah dengan BMT atas dasar negoisasi, dalam menentukan harga jual terlebih dahulu dan dijelaskan kepada nasabah berapa harga belinya kemudian ditambah biaya yang dikeluarkan serta ditambah keuntungan yang akan diperoleh oleh BMT. Sehingga terjadi kesepakatan harga yang selanjutnya melakukan transaksi jual beli secara baik dan benar serta maslahat.

Dalam proses penentuan harga jual dimana bagian pembiayaan biasanya akan menyampaikan tingkat margin yang diinginkan oleh BMT kepada nasabah pembiayaan murabahah, nasabah dapat menawar hanya sampai nilai margin terentu yang tidak dapat diturunkan lagi, seandainya nasabah menginginkan turun lagi, maka kemungkinannya adalah nasabah tersebut ditolak, atau permohonan pengajuanya ditunda sampai diputuskan oleh rapat pimpinan lembaga BMT Masing-masing. Selain itu kesemua BMT didalam keputusanya tetap berdasarkan pada hasil evaluasi $5 \mathrm{C}$, yaitu Character, capacity, capital, collateral dan condition. 
Hasil dari penelitian diatas meunjukan bahwa kebanyakan metode penentuan harga jual murabahah yang dilakukan oleh BMT adalah menggunakan metode margin keuntungan flat dimana perhitungan margin keuntungan terhadap nilai pokok pembiayaan secar tetap dari satu periode keperiode lainya, walaupun jikalau sinasabah ada yang melakukan peunasan dini maka pihak BMT akan memberikan bonus, dan biasanya bonusnya akan menghapus margin keuntungan bulan sesudahnya. Dibawah ini contoh simulasi dari data sekunder yang sudah diolah oleh peneliti, yang lazim dilakukan di BMT yang telah diteliti oleh peneliti:

$\begin{array}{ll}\text { Akad } & : \text { Murabahah } \\ \text { Harga Pokok Pembelian } & : \text { Rp. 40.000.000,- } \\ \text { Biaya-Biaya: } & : \text { Rp. 5.000,- } \\ \text { Administrasi Anggota } & : \text { Rp. 1.000.000,- } \\ \text { Administrasi Pembiayaan } & :- \\ \text { Fidusia/Notaris } & : \text { Rp. 1.005.000,- } \\ \text { Jumlah } & : 12 \text { Bulan } \\ \text { Jangka waktu pembayaran } & : 2 \% \text { X40.000.000 = Rp. 800.000,- } \\ \text { Keuntungan Jual Beli } & : \text { Rp 800.000 X 12 = Rp 9.600.000,- } \\ & : \text { Rp. 49.600.000,- } \\ \text { Harga Jual } & : \text { Intern } \\ \text { Pengikatan } & : \text { Bulanan dengan jumlah angsuran Rp } \\ \text { Sistem Pembayaran } & 4.133 .300,33\end{array}$

Tabel 1. Rincian Angsuran Murabahah

\begin{tabular}{|c|c|c|c|c|}
\hline Angsuran & $\begin{array}{c}\text { Sisa } \\
\text { pembiayaan }\end{array}$ & $\begin{array}{c}\text { Angsuran } \\
\text { pokok }\end{array}$ & $\begin{array}{c}\text { Angsuran } \\
\text { margin }\end{array}$ & Jumlah \\
\hline $\mathbf{1}$ & $36.666 .666,67$ & $3 \cdot 333 \cdot 333,33$ & 800.000 & $4.133 \cdot 333,33$ \\
\hline 2 & $33 \cdot 333 \cdot 333,34$ & $3 \cdot 333 \cdot 333,33$ & 800.000 & $4 \cdot 133 \cdot 333,33$ \\
\hline 3 & 30.000.000,01 & $3 \cdot 333 \cdot 333,33$ & 800.000 & $4 \cdot 133 \cdot 333,33$ \\
\hline 4 & $26.666 .666,68$ & $3 \cdot 333 \cdot 333,33$ & 800.000 & $4 \cdot 133 \cdot 333,33$ \\
\hline 5 & $23 \cdot 333 \cdot 333,35$ & $3 \cdot 333 \cdot 333,33$ & 800.000 & $4 \cdot 133 \cdot 333,33$ \\
\hline 6 & 20.000.000,02 & $3 \cdot 333 \cdot 333,33$ & 800.000 & $4 \cdot 133 \cdot 333,33$ \\
\hline 7 & $16.666 .666,69$ & $3 \cdot 333 \cdot 333,33$ & 800.000 & $4 \cdot 133 \cdot 333,33$ \\
\hline 8 & $13 \cdot 333 \cdot 333,36$ & $3 \cdot 333 \cdot 333,33$ & 800.000 & $4.133 \cdot 333,33$ \\
\hline 9 & 10.000.000,03 & $3 \cdot 333 \cdot 333,33$ & 800.000 & $4 \cdot 133 \cdot 333,33$ \\
\hline 10 & $6.666 .666,7$ & $3 \cdot 333 \cdot 333,33$ & 800.000 & $4.133 \cdot 333,33$ \\
\hline $\mathbf{1 1}$ & $3 \cdot 333 \cdot 333,37$ & $3 \cdot 333 \cdot 333,33$ & 800.000 & $4 \cdot 133 \cdot 333,33$ \\
\hline \multirow[t]{2}{*}{12} & 0.04 & $3 \cdot 333 \cdot 333,33$ & 800.000 & $4 \cdot 133 \cdot 333,33$ \\
\hline & Jumlah & $39.999 .999,96$ & 9.600 .000 & $49.599 \cdot 999,96$ \\
\hline
\end{tabular}


Keterangan: biasanya untuk nominal angsuran dibulatkan, dan nilai nominal pembulatan tersebut dimasukan didalam infaq atau shodaqoh tergantung keikhlasan nasabahnya, misalnya angsuran 4.133.333, 33 diakumulasikan menjadi 4.135.0oo,oo dengan asumsi infaq 1.666,67,- dan asumsi margin 2\% ( ingat besarnya margin dimasing-masing lembaga keuangan syariah berbeda-beda).

Jika dilihat dari penentuan harga jual beli murabahah diatas menunjukan bahwa kebijakan yang dilakukan oleh BMT yang telah diteliti belum sepenuhnya sempurna dengan aturan syariah, walaupun kesemuanya sudah tertuang dalam akad perjanjian murabahah yang telah disetujui oleh masing-masing pihak tanpa adanya unsure paksaan dan yang lebih penting tidak ada tambahan atau biaya lain selain biaya-biaya yang tertera dalam aqad perjanjian. Namun bukan berarti apa yang telah dilakukan oleh lembaga keuangan syariah yang dalam hal ini adalah BMT itu salah semua, hanya ada beberapa hal yang dimungkinkan ada perbaikan. Karena dalam kebijakn ini yang menjadi perhatian adalah paradigm yang dimiliki masih menggunakan prinsip-prinsip yang ada dikonvensional diantaranya :

1. Penetapan margin yang dilakukan di BMT menggunakan fixed rate dengan mtode flat rate dimana penetapan margin dan hutang pokok yang dibebankan setiap bulan adalah sama, sehingga pembayaran total cicilan setiap bulan besarnya tetap sampai selesai. Kibajakan ini bisa saja menjadi pandangan atau persepsi masyarakat yang mengatakan bahwa penentuan harga jual di BMT dan konvensional sama saja atau tidak ada bedanya, bahkan terkadang harga jual atau penetapan margin keuntuntungan yang diberikan BMT lebih mahal ari perbankan konvensional. Padahal nasabah ingin mendapatkan keringanan dengan bertransaksi di BMT, akan tetapi nasabah malah mendapatkan beban harga ddan margin yang lebih tinggi dari pada mereka bertransakasi dengan bank konvensional.

2. Penetapan harga jual murabahah yang dilakukan BMT di Tulungagung memberikan beban keuntungan yang harus diberikan untuk pemegang saham dan dana pihak ketiga kepada nasabah pembiayaan termasuk didalamnya murabahah. Dimana BMT lebih dominan bertumpu pada selisih keuntungan. Oleh karena itu semakin jelas terlihat bahwa dari sisi praktik penentuan harga jual barang pada akad murabahah yang dilakukan oleh BMT belum seluruhnya sempurna dengan aturan syariah. Karena besar ataupun kecil, para nasabah pembiayaan, khususnya murabahah menerima beban margin atau bagi hasil atas keuntungan nasabah penyimpan dan pemilik saham yang seharusnya ditanggung oleh BMT, baik untung ataupun rugi. Salah satu yang menjadi dasar ketidak sesuaian dalam penerappan paradigma ini adalah pemahaman 
yang keliru bahwa BMT harus selalu mendapatkan keuntungan. Selain akan memberatkan nasabah pembiayaan, menjanjikan bahwa suatu usaha akan selalu untung juga dilarang oleh agama. Sebab adakalanya suatu usaha itu mendapatkan keuntungan, namun adakalanya mendapatkan kerugian, utamanya adalah tidak melakukan judi, penipuan, mendzalimi orang lain, serta terbebas dari riba.

\section{KESIMPULAN}

Berdasarkan hasil pembahasan yang telah dilakukan penulis, maka dapat ditarik kesimpulan sebagai berikut:

1. BMT di Tulungagung memiliki kebijakan tersendiri terhadap persyaratan administrasi dalam kelengkapan yang harus dipenuhi dalam pengajuan pembiayaan murabahah. Secara Praktik Semua BMT juga mengacu dalam Prosedur 5C (Caracter, Capacity, Capital,Collateral dan condition) serta mengacu pada prinsip kehati-hatian. Selain itu didalam proses pembelian, BMT tidak melakukan pengadaa barang secara langsung atau memesankan untuk nasabah melainkan mewakilkan langsung kepada nasabah dan nasbah sendiri membelanjakan uang tersebut terhadap barang yang diinginkannya.

2. BMT di Tulungagung menggunakan metode Flat dalam penentuan margin, yang mana metode flat adalah perhitungan margin keuntungan terhadap nilai harga pokok pembiayaan secara tetap dari satu periode keperiode lainya. Selain itu juga ada yang menggunakan sistem annuitas yakni metode pembayaran mendahulukan angusran margin setelah itu membayar angsuran pokok pada waktu jatuh tempo yang dikehendaki. Hal ini mempunyai kesan kepada masyarakat bahwa tidak adanya perbedaan dengan lembaga keuangan lainya. Adapun pola penetapan harga lebih menerapkan sistem dagang yakni lebih mengutamakan negosiasi yang nantinya dari kedua belah pihak saling ridho. belum begitu sempurna dengan aturan syariat yang ada, sebab hal ini dikarenakan dalam proses penentuan harga jual menyandarkan suku bunga yang berlaku dipasar dan beban bagi hasil dengan pemilik saham dan nasabah penyimpanan, selain itu menjadikan suku bunga pesaing yang dalam hal ini lembaga keuangan konvensional sebagai landasan perhitungan.

\section{DAFTAR PUSTAKA}

Al-Muslih, Abdullah dan Shalah Ash-Shawi. 2004. Fikih Ekonomi Keuangan Islam Cetakan Pertama. Jakarta.

Karim, Adiwarman. 2004. Bank Islam. Jakarta: Kharisma Putra Utama Offset. 
Agustianto. BMT Sebagai Lembaga Ekonomi Rakyat, dalam www.agustianto.com. diakses tanggal 27 April 2013

Buchori, Ahmad et al. 2004. Standarisasi Akad perbankan Syariah. Jakarta: Bank Indonesia.

Bimb Institute of Research and Training SDM. 1998. Konsep Syariah Dalam Sistem perbankan Islam. Malasyia: Pernigaan Rita.

Kasmir. 2003. Pemasaran Bank. Jakarta: PT Raja Grafindo Persada.

Moleong, Lexy J. Metodologi Penelitian Kualitatif. Bandung: Remaja Rosda Karya.

Syafi’i Antonio, Muhamad. 2001. Bank Syariah dari Teori ke Praktik. Jakarta: Gema Insan.

Muhammad. 2005. Manajemen Bank Syariah. Jakarta: UPP AMP YKPN.

Rifa'I, Mohd. 2002. Konsep Perbankan Syariah. Semarang: CV. Wicaksana.

Sudjana, Nana. 2003. Tuntunan Penyususunan Karya Tulis Ilmiah. Bandung: Sinar Baru Algesindo.

Bahraesy, Salim . 2007. Terjemah Al Qur'an. Surabaya: Sahabat Ilmu.

Soedrajata, Setyo. 2004. Manajemen Pemasaran Jasa Bank. Jakarta: PT Ikral Mandiri Abadi.

Sutojo, Siswanto. 1997. Manajemen Terapan Bank. Bandung: Pustaka Binaan Pressindo.

Sugiyono. 2005. Penelitian Kualitatif, Bandung: Alfabeta.

Rivai, Veitzal dan Andria Permata Veitzal. 2005. Islamic Financial Managemen. Jakarta : Rajawali Pers.

Zuhaili, Wahbah. 2000. Fiqih Muamalah Perbankan Syariah. Jakarta: Bank Muamalat Indonesia.

Wahidmurni. 2008. Cara Mudah Menulis Proposal dan Laporan Penelitian Lapangan. Malang: UM Pres. 